\title{
PERILAKU REMAJA DALAM PENGGUNAAN PEMBALUT SAAT MENSTRUASI DENGAN KERUSAKAN INTEGRITAS KULIT DI AKPER ADI HUSADA SURABAYA
}

\author{
DEWI ANDRIANI \\ AKADEMI KEPERAWATAN ADI HUSADA SURABAYA \\ andridewi64@gmail.com
}

\begin{abstract}
ABSTRAK
Menstruasi merupakan perdarahan periodik dan siklik berasal dari uterus yang bersifat fisiologis dan mempengaruhi fisik dan psikis setiap wanita terutama perilakunya. Perilaku wanita dalam penggunaan pembalut adalah faktor yang sangat berpengaruh untuk kulit genetalia yang kontak dengan pembalut tersebut. Penelitian ini dilakukan untuk mengetahui adanya hubungan penggunaan pembalut dengan kerusakan integritas kulit yang dialami oleh wanita saat menstruasi. Desain penelitian yang digunakan adalah desain korelasi.Variabel independen perilaku penggunaan pembalut, variabel dependen kerusakan integritas kulit, Dengan jumlah populasi yang ada sejumlah 60 mahasiswa semester 4 dengan penghitungan sampel menggunakan teknik hitungan simple random sampling didapatkan sampel 54 responden. Penelitian dilakukan dengan pengisian kuisioner yang diisi oleh responden. Data reponden yang telah didapat akan diproses dalam tabulasi data. Dari data dan proses penelitian yang sudah dilakukan didapatkan hasil bahwa $81,4 \%$ mahasiswa sudah baik perilakunya dalam penggunaan pembalut dan $37,1 \%$ mahasiswa yang mengalami kerusakan integritas kulitnya dan $62,9 \%$ tidak mengalami kerusakan pada integritas kulitnya. berdasarkan uji korelasi rank spearmean dengan progam IBM statistic, didapatkan hasil bahwa terdapat hubungan yang signifikan antara perilaku penggunaan pembalut saat menstruasi dengan kerusakan integritas kulitnya dengan $\mathrm{p}=0,001$ dengan koefisien sebesar 0,445 yang menunjukkan tingkat korelasi sedang antara penggunaan pembalut dengan kerusakan integritas kulit. Dari hasil tersebut disimpulkan bahwa kerusakan integritas kulit yang dialami akibat dari penggunaan pembalut disebabkan juga oleh faktor-faktor lain. Penggunaan pembalut yang terlalu lama dipakai dalam kondisi yang sudah terkontaminasi dengan darah menstruasi merupakan faktor utama kerusakan integritas kulit disekitar genetalia, sehingga akan menimbulkan rasa tidak nyaman, gatal, dan nyeri.
\end{abstract}

Kata kunci : Menstruasi, perilaku, kerusakan integritas kulit

\section{ABSTRACT}

Menstruation is the periodic and cyclic uterine bleeding which is physiological, psychological and physical affects every women, especially the behavior. Behavior of women in the use of pads is very influential factor for skin genitalia in contact with these pads. This study was conducted to determine the relationship of use sanitary pad with skin integrity damage experienced by women during menstruation. The research was correlation design.Variabel independent was behavior on use sanitary pad, the dependent variable was skin integrity damage. The population was at least 60 4th semester student and used simple random sampling technique, and count samples obtained 54 respondents. Data collected by fulfilled behavior and skin integrity damage questionnaire. Data respondents who have obtained, was processed in the tabulation of the data. From the data and the research process showed that $81.4 \%$ of students had good behavior in the use of pads and $37.1 \%$ of students who experienced skin integrity damage, and $62.9 \%$ did not experienced skin integrity damage. Based on Spearmean Rank Correlation Test with IBM program statistics, showed that there was a significant relationship between the behavior of the use of pads during menstruation to skin integrity damage with $p=0.001$ with a coefficient of 0.445 which indicated moderate level of correlation between the use of pads with skin integrity damage. From these results we concluded that skin integrity damage experienced as the result of the use of pads also caused 
by other factors. The longer use of pads that have been contaminated with menstrual blood was a major skin integrity damage factor around the genitalia, so it will cause discomfort, itching, and pain.

Keywords: Menstruation, behavior, skin integrity damage

\section{PENDAHULUAN}

Menstruasi merupakan perdarahan periodik dan siklik berasal dari uterus yang bersifat fisiologis disertai pelepasan endometrium terjadi pada wanita reproduktif menstruasi juga didefinisikan sebagai perdarahan periodik dari uterus yang di mulai sekitar 14 hari setelah ovulasi secara berkala akibat lepasnya lapisan endometrium uterus ${ }^{9}$. Memelihara kebersihan disaat menstruasi sangatlah penting, banyak remaja (80\%) mengabaikannya, sehingga menyebabkan kerusakkan integritas kulit karena penggunaan pembalut yang salah. Menstruasi biasanya berlangsung selama 515 hari. Pada 5 hari pertama menstruasi banyak darah yang keluar sehingga membutuhkan pembalut. Darah yang keluar dari vagina bermacam-macam, tidak hanya darah menstruasi tetapi juga darah penyakit, seperti myoma, kanker dan kista.

Wanita membutuhkan pembalut berbahan aman, dan berabahan utama kapas. Pada kenyataannya pembalut saat ini banyak berbahan utama kertas bekas atau serbuk kayu. Kertas bekas di daur ulang untuk menghilangkan bau dengan zat yang digunakan adalah zat dioxin. Menurut WHO bahwa dioxin menyebabkan kanker. Pemakaian pembalut berkualitas buruk berdampak negatif pada wanita, seperti infeksi organ intim, kerusakan integritas kulit(iritasi), gatal-gatal, dan menimbulkan bau yang tidak sedap. Apabila pembalut tidak diganti selama 4 jam sekali dalam sehari, maka kuman atau bakteri akan berkembang biak dan menimbulkan penyakit seperti, myoma, kista dan kanker.

Hasil penelitian menyatakan bahwa dioksin meningkatkan kejadian endometriosis dan pembesarannya pada primata, mempengaruhi kesehatan reproduksi, system endokrin, toksik pada sistem imunitas dan perkembangan serta bersifat karsinogenik ${ }^{12}$. Dioxin walaupun dalam jumlah sedikit, terakumulasi dalam jaringan lemak (endometriosis association, 2004) dimana intervensinya sampai pada tingkat sel, yang akhirnya mempengaruhi DNA, metabolisme hormon, faktor pertumbuhan, reproduksi, endokrin, dan fungsi imunitas ${ }^{1}$.

\section{METODE PENELITIAN}

Metode penelitian yang digunakan desain korelasi, populasi remaja putri semester 4 di Akademi Keperawatan Adi Husada Surabaya berjumlah 60 orang. Pengambilan sample dalam penelitian ini dengan tehnik simple random sampling dengan mengambil sampel 52 orang dengan cara menulis nama setiap anggota populasi pada secarik kertas, diletakkan di kotak, diaduk, dan diambil secara acak, setelah semuanya terkumpul. Adapun kriteria sampel adalah responden berada dalam kelas saat kuisioner diberikan, bersedia mengisi angket.

Variabel independen: penggunaan pembalut dan variabel dependen: kerusakan integritas kulit. Uji statistik yang digunakan pada penelitian ini yaitu Rank Spearman yang bertujuan unutk membandingkan sikap dan perilaku dalam penggunaan sesuatu, dengan $\alpha=0,05$. Penelitian dilaksanakan pada Oktober-Desember 2015 di Akademi Keperawatan Adi Husada Surabaya

\section{HASIL}

Tabel 1 Tabulasi Karakteristik Responden

\begin{tabular}{llrr}
\hline No & \multicolumn{1}{c}{ Kakteristik } & n & $\%$ \\
\hline \multirow{2}{*}{1} & Umur (tahun) & & \\
\cline { 2 - 4 } & $19-20$ & 30 & 56 \\
\cline { 2 - 4 } & $21-22$ & 18 & 33 \\
\cline { 2 - 4 } & $>22$ & 6 & 28 \\
\hline 2 & $\begin{array}{l}\text { Posisi Anak } \\
\text { dalam keluarga }\end{array}$ & & \\
\cline { 2 - 4 } & Tunggal & 12 & 22 \\
\cline { 2 - 4 } & Pertama & 14 & 26 \\
\cline { 2 - 4 } & Bukan pertama & 18 & 33 \\
\cline { 2 - 4 } & Bungsu & 10 & 19 \\
\hline
\end{tabular}




\begin{tabular}{llll}
\hline 3 & Umur Menarche & & \\
\cline { 2 - 4 } & $<15$ & 15 & 28 \\
\cline { 2 - 4 } & $>15$ & 39 & 72 \\
\hline 4 & Tinggal bersama & & \\
\cline { 2 - 4 } & Orang tua & 22 & 41 \\
\cline { 2 - 4 } & Kos & 32 & 59 \\
\hline
\end{tabular}

Berdasarkan tabel 1 menunjukkan bahwa responden paling banyak berumur berkisar 19-20 tahun dengan jumlah 30 responden (56\%). Rata-rata responden merupakan anak kedua atau lebih dengan jumlah 18 responden (33\%), terdapat 14 responden $(26 \%)$ menjadi anak 1 di keluarganya.

Berdasarkan tabel 1 menunjukan bahwa sebagian respon yang diteliti $72 \%$ (39 responden) mengalami menstruasi pertama kali pada umur lebih dari 15 tahun.

Berdasarkan tabel 1 menunjukkan bahwa 59\% dari responden yang diteliti tinggal sendiri atau kos. Dan 41\% responden tinggal bersama orang tua.
Tabel 2 Karateristik Perilaku Responden Dalam Penggunaan Pembalut Mahasiswa Semester 4

\begin{tabular}{llll}
\hline No & Variabel & $\mathrm{n}$ & $\%$ \\
\hline 1 & $\begin{array}{l}\text { Perilaku } \\
\text { penggunaan } \\
\text { pembalut }\end{array}$ & & \\
\cline { 2 - 4 } & Baik & 2 & 3,7 \\
\cline { 2 - 4 } & Cukup & 44 & 81.4 \\
\cline { 2 - 4 } & Kurang & 8 & 14.9 \\
\hline 2 & $\begin{array}{l}\text { Kerusakan } \\
\text { integritas kulit }\end{array}$ & & \\
\cline { 2 - 4 } & Mengalami & 20 & 37.1 \\
\cline { 2 - 4 } & Tidak & 34 & 62.9 \\
\hline
\end{tabular}

Menunjukkan 44 responden memiliki perilaku yang cukup baik (81.4\%) dalam menggunakan pembalut saat menstruasi.

Menunjukkan bahwa terdapat 20 (37.1\%) responden mengalami kerusakan integritas kulit dan 34 (62.9\%) responden tidak mengalami kerusakan integritas kulitnya akibat pemakaian pembalut saat menstruasi.

\section{Data Khusus}

Tabel 3 Tabulasi Silang

\begin{tabular}{lcccc}
\hline \multicolumn{1}{c}{ Variabel } & \multicolumn{3}{c}{ Perilaku } & Total \\
\cline { 1 - 4 } Integritas Kulit & Baik & Cukup & Kurang & \\
\cline { 1 - 4 } Rusak & 0 & 13 & 7 & 20 \\
& & $(24.1 \%)$ & $(13 \%)$ & $(37.1 \%)$ \\
\hline Tidak rusak & 2 & 31 & 1 & 34 \\
& $(3.7 \%)$ & $(57.4 \%)$ & $(1.8 \%)$ & $(62.9 \%)$ \\
\hline Total & 2 & 44 & 8 & 54 \\
& $(3.7 \%)$ & $(81.4 \%)$ & $(14.9 \%)$ & $(100 \%)$ \\
\hline
\end{tabular}

Uji Spearman Rank $\mathrm{p}=0.001(\alpha=0.05)$

Coeffisien Correlation $\mathrm{r}=0.445$

Menunjukkan tidak ada responden berperilaku baik dalam penggunaan pembalut mengalami kerusakan integritas kulit, berperilaku cukup baik mengalami kerusakan integritas kulit sebanyak 13 $(24.1 \%)$ dan responden berperilaku kurang baik mengalami kerusakan integritas pada kulitnya sebanyak 7 (13\%) responden.

\section{PEMBAHASAN}

\section{Perilaku dalam penggunaan pembalut}

Pada tabel 2 menunjukkan bahwa 44 $(81,4 \%)$ responden berperilaku cukup baik dalam menggunakan pembalut saat menstruasi, $\quad$ sedangkan $8 \quad(14.9 \%)$ berperilaku kurang baik dalam menggunakan pembalut saat menstruasi. Pendidikan dapat mempengaruhi seseorang termasuk perilaku seseorang akan pola terutama dalam motivasi untuk bersikap serta dalam pembangunan kesehatan ${ }^{4}$. Jadi dapat dikatakan bahwa pendidikan dapat menuntun untuk mendapatkan informasi yang lebih. mahasiswa akper Adi Husada Semester 4 berdasarkan pendidikan dan pengetahuan mereka telah memahami pentingnya menjaga kebersihan dalam penggunaan pembalut selama menstruasi, 
mereka juga telah mendapatkan perkuliahan tentang kesehatan reproduksi. Menurut Pujiastuti (2003), kesalahan yang sering dilakukan saat pemakaian pembalut: membuka dan memasang pembalut tanpa mencuci tangan terlebih dahulu, menyimpan pembalut di tempat yang lembab seperti kamar mandi, menggunakan pembalut yang telah kadaluarsa, pemilihan pembalut tanpa mempertimbangkan kualitas pembalut, memakai pembalut yang mengandung bahan penghilang bau, serta pemakaian pembalut yang terlalu lama. Pada saat mentruasi darah yang keluar apabila menumpuk terlalu lama maka akan menjadi media perkembang biakan kuman apalagi bahan pembalut yang berasal dari serbuk kayu ataupun kertas yang daur ulang akan berbahaya apabila tidak sering melakukan ganti pembalut. Perilaku menunda dalam mengganti pembalut sering menjadi alasan remaja karena kurang perduli dengan pentingnya menjaga kesehatan maka masih ada responden yang kurang baik perilakunya dalam penggantian pembalut saat menstruasi. Menurut penelitian Rogers (1974) dikutip Notoatmodjo (2003), mengungkapkan bahwa sebelum orang melakukan perilaku terjadi proses berurutan yakni: kesadaran (awareness) Seseorang menyadari dan mengetahui terlebih dahulu terhadap stimulus atau objek. Tertarik (interest) Seseorang mulai tertarik pada stimulus yang diberikan pihak lain.

\section{Kerusakan integritas kulit}

Pada Tabel 2 menunjukkan terdapat $20(37,1 \%)$ responden yang diteliti mengalami kerusakan integritas kulitnya akibat pemakaian pembalut saat menstruasi. Menurut Aziz Alimul (2008) terdapat beberapa faktor yang mempengaruhi kerusakan kulit yaitu faktor eksternal (lingkungan) yang mempengaruhi kesehatan kulit berupa paparan substansi kimia, faktor mekanik (misalnya terpotong, tertekan, dan akibat restrein), kelembaban, immobalisasi fisik, radiasi. Selain itu, faktor internal juga berpengaruh pada kulit yaitu adanya ketidakseimbangan status nutrisi (misalnya: obesitas, kekurusan), tidak memiliki defisit kekebalan tubuh yang baik dan adanya faktor-faktor perkembangan. Hal tersebut menunjukkan bahwa, kerusakan integritas kulit yang terjadi saat menggunakan pembalut tidak lepas dari faktor-faktor tersebut di tambah dengan keelastisitas dan kondisi pada kulit setiap orang. Kekebalan tubuh seseorang juga sangat mempengaruhi kondisi kulit. Reaksi yang ditimbulkan bermacam, sering kali diawali dengan rasa gatal pada kulit, kemerahan dan timbul goresan luka.

\section{Hubungan perilaku penggunaan pembalut dengan kerusakan integritas kulit}

Tabel 3 menunjukkan hubungan perilaku remaja dalam penggunaan pembalut Saat Menstruasi Dengan Kerusakan Integritas Kulit. Responden yang berperilaku baik tidak mengalami kerusakan integritas kulit, reponden yang berperilaku cukup baik masih ditemukan terjadi kerusakan integritas kulit sebanyak 13 responden. Berdasarkan uji spearman diperoleh hasil p 0,001 dengan $\alpha 0,05$. Hal ini menunjukkan bahwa terdapat korelasi yang signifikasi antara perilaku penggunaan pembalut dengan kerusakan integritas kulit, koefisien sebesar 0,445. Dilihat dari kriteria tingkat hubungan (koefisien korelasi) antar variable menurut uji spearmean yang berkisar 0,00 sampai 1,00 menunjukan bahwa hasil dari penelitian memiliki tingkat korelasi sedang antara perilaku penggunaan pembalut dengan kerusakan integritas kulit. Perilaku remaja dalam mengahadapi masa menstruasi yang kurang baik merupakan faktor utama dari kerusakan pada area genetalia disertai dengan penggunaan bahan pembalut yang tidak sesuai dengan standart kesehatan dan cara pemakaiannya. Menurut Notoatmodjo (2003) bahwa perilaku untuk memilih produk pembalut dan kualitas bahan yang akan digunakan ditentukan sendiri oleh setiap individu, banyaknya jumlah produk yang ditawarkan dimasyarakat melalui iklan-iklan yang membuat ketertarikan wanita untuk menggunakannya dengan mencoba produk yang ditawarkan dengan dasar kebutuhan, biaya, dan popularitas dari produk tersebut 
tanpa melihat kandungan bahan yang terkandung dan efek samping yang ditimbulkan, tidak hanya itu perilaku dalam penggunaan produk pembalut sangat menentukan bagaimana reaksi tubuh terhadap pembalut yang digunakan. Pembalut yang terlalu lama dipakai dalam kondisi yang sudah kotor dengan darah menstruasi merupakan objek terbaik bakteri dalam berkembang, perkembangan bakteribakteri tersebut menimbulkan dampak pada system reproduksi dan pada area kulit yang terpapar bakteri tersebut, reaksi yang ditimbulkan berupa rasa gatal, kemerahan, terasa nyeri dan tidak jarang tumbuh bisul pada area genetalia.

\section{SIMPULAN}

Perilaku penggunaan pembalut dengan kerusakan integritas kulit saat menstruasi, hasil penelitian menunjukkan bahwa menunjukkan bahwa 44 (81.4\%) responden cukup baik dalam perilakunya menggunakan pembalut saat menstruasi. Sedangkan $8(14.9 \%)$ kurang baik dalam perilakunya menggunakan pembalut saat menstruasi. terdapat 20 responden $(37.1 \%)$ yang diteliti mengalami kerusakan integritas kulitnya akibat pemakaian pembalut saat menstruasi.

Kerusakan integritas kulit saat menstruasi, hasil penelitian menunjukan bahwa terdapat 20 responden $(37.1 \%)$ yang diteliti mengalami kerusakan integritas kulitnya akibat pemakaian pembalut saat menstruasi. Dan 34 responden (62,9\%) tidak mengalami kerusakan integritas kulitnya akibat pemakaian pembalut saat menstruasi.

Hubungan penggunaan pembalut dengan kerusakan integritas kulit, dari hasil uji statistik spearman tentang hubungan perilaku penggunaan pembalut dengan kerusakan integritas kulit diperoleh hasil $\mathrm{p}=0.001$ Hal ini menunjukkan bahwa terdapat korelasi yang signifikasi antara perilaku penggunaan pembalut dengan kerusakan integritas kulit. Koefisien atau tingkat hubungan antara perilaku penggunaan pembalut dengan kerusakan integritas kulit sebesar $\mathrm{r}=0.445$. Menunjukan bahwa hasil dari penelitian memiliki tingkat korelasi sedang antara perilaku penggunaan pembalut dengan kerusakan integritas kulit.

\section{SARAN}

Perempuan yang sudah mengalami menstruasi harus lebih memperhatikan pemilihan bahan pembalut yang aman dan sehat, karena kulit area genetalia sangat sensitif terhadap paparan benda asing terutama pembalut. Penggunaan pembalut harus dipahami, pembalut yang terlalu lama dipakai dalam kondisi yang sudah kotor dengan darah menstruasi merupakan objek terbaik bakteri dalam berkembang, sehingga menimbulkan dampak pada sistem reproduksi dan pada area kulit yang terpapar bakteri tersebut, reaksi yang ditimbulkan berupa rasa gatal, kemerahan, terasa nyeri dan tidak jarang tumbuh bisul pada area genetalia.

\section{DAFTAR PUSTAKA}

1. Bobak. 2004. Buku Ajar Keperawatan Maternitas Edisi IV. Jakarta: Penerbit Buku Kedokteran EGC

2. Nursalam. 2013. Metodologi penelitian ilmu keperawatan. Jakarta: Salemba medika

3. Nursalam. 2008. Konsep dan penerapan metodologi penelitian ilmu keperawatan. Jakarta: Salemba Medika

4. Notoatmodjo,Soekidjo. 2007. Promosi kesehatan dan ilmu perilaku. Jakarta : Rineka cipta

5. Pearce, Evelyn. 2011. Anatomi dan Fisiologis Untuk Para Medis. Jakarta: PT. Gramedia Pustaka utama.

6. Sarwono.2007. Psikologi Remaja. Jakarta: PT Rajagrafido Persada.

7. Syaifuddin. 2011. Fisiologi Tubuh Manusia. Jakarta:Salemba Medika.

8. Varney,H. 2007. Buku Ajar Asuhan Kebidanan Volume 2. Jakarta : EGC.

9. Wiknjosastro, S. 2010. Ilmu Kandungan. Jakarta : YBPSP

10. Notoatmodjo, Soekidjo. 2010. Metodologi Penelitian Kesehatan. Jakarta: Rineka Cipta 
11. Watson, Roger. 2002. Anatomi \& Fisiologi untuk perawat. Edisi 10. Jakarta: EGC

12. Putri. Pilih pembalut yang aman. Mimbar. November. 2011:Vol.15 no 4. 